\title{
Urban Agglomerations as Centers of Regional Economic Development*
}

\author{
Konstantin Getmantsev \\ Department of Organization and Planning of Local \\ Development \\ Kuban State University \\ Krasnodar, Russia \\ E-mail: kot34@mail.ru \\ Evgeniya Atamas \\ Department of State and Municipal Administration \\ Kuban State University \\ Krasnodar, Russia
}

\author{
Tatyana Myasnikova \\ Department of State and Municipal Administration \\ Kuban State University \\ Krasnodar, Russia
}

\author{
Kristina Silchenko \\ Department of Investments and Development of Small and \\ Average Business of Krasnodar Krai \\ Krasnodar, Russia \\ E-mail: allthat@bk.ru
}

\begin{abstract}
The present article studies the issues of evaluating the potential of large urban agglomerations for attracting financial and investment resources into the regional economic system. By the example of the Krasnodar urban agglomeration, the authors study the place and role of agglomerations in modern regional economic development, which is essential under the current economic and financial crisis in Russia and the need for new growth areas and resources for economic development.
\end{abstract}

\section{Keywords-investments; agglomeration; regional economy}

\section{INTRODUCTION}

The process of shaping agglomerations in regions implies creating the centres of gravity of the population, entrepreneurship and capital, capable of performing the functions of main stations in regional development. Underestimating the process results in underestimating the positive effect of agglomerations on regional development, while recognizing their role necessitates evaluating their impact and developing coherent regional policy aimed at supporting and developing regional agglomerations.

In recent years, scientific literature and the media have provided increased information on large urban agglomerations being shaped in the south of Russia, in Krasnodar Krai precisely. Meanwhile, the given data is rather contradictory: the total number of agglomerations, their elements and economy structure, etc. are presented differently. However, this can be explained by the fact that the concept of an urban agglomeration has not yet been enshrined in Russian legislation. Therefore, it is a matter of priority to define what an agglomeration is, what agglomerations are present in the south of Russia and what

*Fund: The study was carried out with financial support from the Russian Foundation for Basic Research in the framework of the scientific project No. 18-410-230026 p a "The model of public network management of the strategy for socio-economic development of Krasnodar Krai". main socio-economic characteristics they possess.

\section{THE CONCEPT OF RESEARCH}

When examining the problems of urban agglomerations development, we apply the approach to studying agglomerations proposed by researchers G.M. Lappo, P.M. Polyan and T.I. Selivanova [2], [6], [7]. Among the main criteria for identifying the boundaries of urban agglomerations they name the presence of an urban nucleus with the population of not less than 250 thousand people, at least two urban settlements around the nucleus, circular migration, accessibility by transport (within 1.5 hours), and well-developed urban infrastructure. [6].

A. Neshchadin and A. Prilepin extend this list with such factors as the presence of housing property in suburban areas owned by urban residents, the availability of unoccupied land around the city, developed road networks, established industrial communications; and the presence of territories with recreational potential [9].

However, most frequently it is exactly accessibility by transport, which is used to define agglomerations [12]. Accordingly, the structure of the Krasnodar urban agglomeration can be determined as presented in "Table I" [5]. 
TABLE I. THE MAIN INDICATORS CHARACTERIZING THE KRASNODAR URBAN AGGLOMERATION

\begin{tabular}{|l|l|l|l|l|}
\hline $\begin{array}{c}\text { Territory (municipal } \\
\text { entity) }\end{array}$ & Area, sq. km. & \multicolumn{1}{|c|}{$\begin{array}{c}\text { Population, } \\
\text { thousand pers. }\end{array}$} & $\begin{array}{l}\text { Distance to Krasnodar, } \\
\text { accessibility by transport, } \\
\text { km }\end{array}$ & \multicolumn{1}{|c|}{ Other criteria } \\
\hline $\begin{array}{l}\text { Krasnodar, } \\
\text { agglomeration nucleus }\end{array}$ & 841.4 & 861.2 & - & $\begin{array}{l}\text { Urban residents having housing property in the } \\
\text { rural district, closest to the city; the availability of } \\
\text { unoccupied land around the city; urban residents } \\
\text { developing business in the rural district. }\end{array}$ \\
\hline Dinskoy District & 1352.0 & 131.0 & $\begin{array}{l}30 \mathrm{~km} ; \text { highway "Don"; } \\
\text { two regional motorways, } \\
\text { three railway lines }\end{array}$ & $\begin{array}{l}\text { Transit traffic; labour migration to the city; urban } \\
\text { residents buying real estate in the district; location } \\
\text { of city industries in the district. }\end{array}$ \\
\hline $\begin{array}{l}\text { Krasnoarmeyskiy } \\
\text { District }\end{array}$ & 1897.7 & 103.5 & $70 \mathrm{~km} ;$ & $\begin{array}{l}\text { Urban residents locating business in the district; } \\
\text { labour migration; urban residents buying real } \\
\text { estate in the border areas, construction of } \\
\text { suburban settlements. }\end{array}$ \\
\hline Severskiy District & 2122.0 & 115.1 & $\begin{array}{l}30 \mathrm{~km} ; \text { highway E 115; } \\
\text { railway line Krasnodar - } \\
\text { Novorossiysk }\end{array}$ & $\begin{array}{l}\text { Transit traffic; labour migration to the city; urban } \\
\text { residents buying real estate in the district; location } \\
\text { of city industries in the district; tourism. }\end{array}$ \\
\hline Ust-Labinskiy District & 1130.0 & 112.2 & $\begin{array}{l}59 \mathrm{~km} ; \text { highway, railway } \\
\text { line }\end{array}$ & $\begin{array}{l}\text { Transit traffic; labour migration to the city; urban } \\
\text { residents buying real estate in the district; location } \\
\text { of city industries in the district. }\end{array}$ \\
\hline Goryachy Klyuch & 1755.6 & 59.3 & $\begin{array}{l}60 \mathrm{~km} \text {; highway, railway } \\
\text { line }\end{array}$ & $\begin{array}{l}\text { Resort city: labour migration; urban residents } \\
\text { buying real estate in the district; location of hotel } \\
\text { business in the city. }\end{array}$ \\
\hline
\end{tabular}

The main characteristic feature of the Krasnodar urban agglomeration is that its existence and development is provided by transport routes M-4 "Don", M-25, A-146 and M-21. Another feature is its structural representation with one major city (Krasnodar) and several rural districts (raions): the Dinskoy, Krasnoarmeyskiy, Severskiy and Ust-Labinskiy. Goryachy Klyuch, nominally being a city, is essentially a rural district [5]. The main characteristics of the Krasnodar urban agglomeration, including the figures of its municipal entities, are demonstrated in "Table II" [11].

TABLE II. THE MAIN SOCIO-ECONOMIC INDICATORS OF THE Krasnodar Urban AgGlomeration (TOTAL of All Municipal ENTITIES CONSTITUTING THE AGGLOMERATION) AND ITS ROLE IN THE REGION

\begin{tabular}{|c|l|l|l|l|l|}
\hline & \multicolumn{1}{|c|}{$\mathbf{2 0 1 4}$} & $\mathbf{2 0 1 5}$ & $\mathbf{2 0 1 6}$ & $\mathbf{2 0 1 7}$ & $\mathbf{2 0 1 8}$ \\
\hline $\begin{array}{c}\text { Agglomeration } \\
\text { territory, sq. km. }\end{array}$ & 9479.7 & 9479.7 & 9479.7 & 9479.7 & 9479.7 \\
\hline Share, region-wide & $12.5 \%$ & $12.5 \%$ & $12.5 \%$ & $12.5 \%$ & $12.5 \%$ \\
\hline $\begin{array}{c}\text { Population, } \\
\text { thousand pers. }\end{array}$ & 1347 & 1368.3 & 1392.3 & 1419.2 & 1448.7 \\
\hline Share, region-wide & $26 \%$ & $26 \%$ & $26 \%$ & $26 \%$ & $27 \%$ \\
\hline $\begin{array}{c}\text { Volume of } \\
\text { industrial } \\
\text { production, mln. } \\
\text { RUB }\end{array}$ & 68311 & 72548 & 67814 & 85384 & 90167 \\
\hline Share, region-wide & $33.5 \%$ & $34.7 \%$ & $35.1 \%$ & $35.8 \%$ & $35.6 \%$ \\
\hline $\begin{array}{c}\text { Capital } \\
\text { investment, mln. } \\
\text { RUB }\end{array}$ & 196691 & 172159 & 223703 & 230210 & 237496 \\
\hline Share, region-wide & $49 \%$ & $34 \%$ & $37 \%$ & $32 \%$ & $40 \%$ \\
\hline $\begin{array}{c}\text { Agricultural } \\
\text { production, mln. } \\
\text { RUB }\end{array}$ & 4407 & 4312 & 4582 & 4423 & 4805 \\
\hline Share, region-wide & $12.7 \%$ & $10.2 \%$ & $11.8 \%$ & $12.4 \%$ & $11.5 \%$ \\
\hline $\begin{array}{c}\text { Retail turnover, } \\
\text { mln. RUB }\end{array}$ & 147018 & 155014 & 162312 & 175215 & 180630 \\
\hline Share, region-wide & $33.4 \%$ & $34.9 \%$ & $35.4 \%$ & $36.1 \%$ & $37.8 \%$ \\
\hline
\end{tabular}

Consequently, with $12.5 \%$ of the region's territory, the Krasnodar urban agglomeration accounts for about $27 \%$ of the region's population and contributes about $35.6 \%$ of industrial production, $11.5 \%$ of agricultural production, up to $37.8 \%$ of trade volume and $40.3 \%$ of total investments in the region.

\section{EVALUATING THE ROLE OF THE AGGLOMERATION IN THE REGION}

As centres of regional economic activity, urban agglomerations attract people and investments and concentrate regional industrial enterprises. For this reason, the Krasnodar urban agglomeration performs an essential role in the development of Krasnodar Krai and its socioeconomic activity.

Primarily, let us consider general population figures for the Krasnodar urban agglomeration, which are presented in "Table III" [11].

TABLE III. THE POPUlation OF THE KRASNODAR URBAN AgGlOMERATION, THOUSAND PERS.

\begin{tabular}{|l|l|l|l|l|l|}
\hline \multicolumn{1}{|c|}{ Territory } & $\mathbf{2 0 1 4}$ & $\mathbf{2 0 1 5}$ & $\mathbf{2 0 1 6}$ & $\mathbf{2 0 1 7}$ & $\mathbf{2 0 1 8}$ \\
\hline $\begin{array}{l}\text { Total for the } \\
\text { agglomeration }\end{array}$ & 1347 & 1368.3 & 1392.3 & 1419.2 & 1448.7 \\
\hline Goryachy Klyuch & 57.4 & 58.3 & 59.3 & 60.4 & 61.9 \\
\hline Krasnodar & 834.1 & 851.2 & 871.2 & 893.3 & 917.9 \\
\hline Dinskoy District & 127 & 128.7 & 131 & 133.4 & 136.3 \\
\hline $\begin{array}{l}\text { Krasnoarmeyskiy } \\
\text { District }\end{array}$ & 102.6 & 103.1 & 103.5 & 104.1 & 104.3 \\
\hline $\begin{array}{l}\text { Severskiy } \\
\text { District }\end{array}$ & 113.1 & 114.4 & 115.1 & 116.3 & 117.1 \\
\hline $\begin{array}{l}\text { Ust-Labinskiy } \\
\text { District }\end{array}$ & 112.8 & 112.6 & 112.2 & 111.7 & 111.2 \\
\hline
\end{tabular}

The presented data demonstrates a positive trend in population growth in the Krasnodar urban agglomeration. Annual population growth rate is estimated at 25-30 thousand people [11]. However, the population increase is not significant; in fact, it amounts to $1.5-2 \%$ per year. 
Meanwhile, according to the population growth indicator, the municipal entities constituting the agglomeration are characterized differently: the population rate in Krasnodar, the Dinskoy and Severskiy districts is growing, while in the other entities of the agglomeration it remains practically unchanged.
The data on mobility rates for the Krasnodar urban agglomeration is shown in "Table IV" and gives rise to interesting conclusions. [1].

TABLE IV. InDiCATORS OF Migration GAIN IN THE KRASNODAR URban AGGLOMERATION

\begin{tabular}{|c|c|c|c|c|c|}
\hline Territory & 2014 & 2015 & 2016 & 2017 & 2018 \\
\hline Total for the agglomeration & 26746 & 61514 & 46338 & 72508 & 45800 \\
\hline Goryachy Klyuch & 646 & 934 & 959 & 1172 & 1399 \\
\hline Krasnodar & 6549 & 16268 & 17668 & 19157 & 20522 \\
\hline Dinskoy District & 809 & 1878 & 2229 & 2382 & 2685 \\
\hline Krasnoarmeyskiy District & 650 & 737 & 463 & 708 & 218 \\
\hline Severskiy District & 428 & 1698 & 1006 & 1184 & 919 \\
\hline Ust-Labinskiy District & -87 & 128 & -185 & -301 & -185 \\
\hline
\end{tabular}

According to "Table IV", the agglomeration attracts significant numbers of migrants, but the figures differ with entities. Thus, the territories most attractive for migrants are Krasnodar, the Dinskoy and Severskiy districts, i.e. the administrative centre of the region and the nearest municipal entities. The rest of the agglomeration in their turn, provide migration primarily to the city, Krasnodar. This fact can be explained by circular migration: people eventually move to Krasnodar, thereby contributing to positive net migration in the city.

As centres of regional economic activity, urban agglomerations attract significant investment resources. The investment process is stimulated by increasing the efficiency of investments. Unlike regular investments in the economy of rural areas, for instance, investing in the agglomeration economy provides synergistic effect: growing economic opportunities in the area and accelerating economic processes, which in its turn encourages new investments. Therefore, agglomerations tend to have positive investment trends; fluctuations or decreasing investment volumes indicate serious problems in the economic development.

"Table V" provides the data on the investment volumes in the economy of the Krasnodar urban agglomeration [3].

TABLE V. INVESTMENT VOLUMES IN THE KRASNODAR URBAN AGGLOMERATION, MLN. RUB

\begin{tabular}{|c|c|c|c|c|c|}
\hline Territory & 2014 & 2015 & 2016 & 2017 & 2018 \\
\hline Total for the agglomeration & 196691 & 172159 & 223703 & 230210 & 237496 \\
\hline Goryachy Klyuch & 876 & 981 & 2088 & 2276 & 2490 \\
\hline Krasnodar & 189952 & 162528 & 209786 & 207740 & 217254 \\
\hline Dinskoy District & 982 & 1643 & 2060 & 2003 & 4529 \\
\hline Krasnoarmeyskiy District & 1352 & 1701 & 717 & 1153 & 1284 \\
\hline Severskiy District & 2351 & 3647 & 7041 & 14470 & 9604 \\
\hline Ust-Labinskiy District & 1178 & 1659 & 2011 & 2568 & 2335 \\
\hline
\end{tabular}

The volume of attracted investments is growing throughout the Krasnodar agglomeration. In terms of growth rates, Krasnodar, Goryachy Klyuch, the Dinskoy and Severskiy districts act as investment attraction centres and significantly outperform the Ust-Labinskiy District and especially the Krasnoarmeyskiy District where the volume of attracted investments is actually decreasing. Krasnodar, attracting the biggest share of all investments $(91.5 \%)$ is followed by the Severskiy District, providing up to $4 \%$ of total investments [3].

According to the conducted study, the period of 20162017 was characterized by the decline in investments. The results of the year 2018 were relatively successful and amounted to $40 \%$, but failed to reach the level of $49 \%$ in 2015. The main reason for declining investments in the agglomeration is the slowing pace of investment growth in all municipal entities, except Krasnodar. It indicates that investors do not consider suburban territories as alternatives to investing in the agglomeration nucleus. Thus, there is no positive effect of stimulating investments on the periphery of the agglomeration and more distant areas.
The allocation of the attracted investment resources is of special interest. In the present research, we analysed the data of the Consortium Leontief Centre - AV Group [10] and the Investment Portal of Krasnodar region [3].

The presented data refers to 2018 and reflects the allocation of investments in the municipal entities constituting the Krasnodar urban agglomeration. In Krasnodar, the nucleus of the agglomeration, investments were made into trade, industry, transport, and energy. The least investment was made in agriculture, since the city is only partially agricultural. Therefore, it can be concluded that investors recognize the city as the centre for investment projects in trade, industry and fuel and energy complex.

The Severskiy District and Goryachy Klyuch, have similar structures of investments. They form the conditional industrial centre of the agglomeration and, due to their favourable location in close proximity to the city of Krasnodar, investors may consider them as alternatives to investing in a more expensive city. In contrast, the Krasnoarmeyskiy District is a more "traditional" agricultural 
region and investors do not consider it as a territory of industrial development.

As for the Dinskoy and Ust-Labinskiy districts, they have the in-between position: on the one hand, they are characterized by substantial investment in the agro-industrial sector, while on the other hand, have high rates of industrial investment. Thus, they can be broadly divided into two parts: the one that is focused on the city and its industrial development, and the other one that has retained the traditional rural economy. Investors consider these districts accordingly: the agricultural centre and the industrial centre in relatively close proximity to the city.

High figures on investment in the social sphere result from the implementation of programs aimed at the construction of social facilities and schools (under the subprogram "Stimulating the development of housing programs in the constituent entities of the Russian Federation" of the Federal Target Program "Housing") and major social projects [8].

One of the key points in positioning agglomerations in the regional economy is their capability of concentrating production and creating stimulus for the regional industrial development. This is provided by the fact that most agglomerations are based on industrial cities. There may be cities with a different specialization, but generally, there is industry concentration in agglomerations.

In his work entitled "Functions of city agglomerations in regional economy and their state support", S.I. Kutovoj describes this feature of urban agglomerations in the regional economy through the concept of "propulsive centres" of regional industrial development [4]. Agglomerations become centres of industrial production, which may result in the development of regional clusters, encouraging the development of the regional economy. Another reason for concentrating industry in agglomerations is that gradually, due to the spatial development of the agglomeration, production is inevitably transferred from the nucleus of the agglomeration to its periphery, which may work as a stimulus for the development of the periphery and more distant territories. [4].

Next, let us assess the dynamics of industrial production in agglomerations in order to evaluate its impact of the regional development. "Table VI" analyses the volume of industrial production in the Krasnodar urban agglomeration [11].

TABLE VI. The Volume of Industrial Production in the KRASNODAR URban AgGLOMERATiOn, MLN. RUB

\begin{tabular}{|l|l|l|l|l|l|}
\hline \multicolumn{1}{|c|}{ Territory } & \multicolumn{1}{c|}{$\mathbf{2 0 1 4}$} & \multicolumn{1}{c|}{$\mathbf{2 0 1 5}$} & \multicolumn{1}{|c|}{$\mathbf{2 0 1 6}$} & \multicolumn{1}{|c|}{$\mathbf{2 0 1 7}$} \\
\hline Total for the agglomeration & 91651.7 & 119678 & 184442.4 & 205136.1 & 263884.5 \\
\hline Goryachy Klyuch & 1161.3 & 1516.7 & 1918.6 & 1795.2 & 1832.2 \\
\hline Krasnodar & 56120.4 & 85624.3 & 144684 & 165681 & 220553 \\
\hline Dinskoy District & 6478.5 & 8766.4 & 9239.3 & 12172.3 & 12364.2 \\
\hline Krasnoarmeyskiy District & 3864.2 & 4981.6 & 4622.5 & 4368.3 & 4562.6 \\
\hline Severskiy District & 20893.7 & 14781.2 & 16953.1 & 12766.6 & 17155.2 \\
\hline Ust-Labinskiy District & 3133.6 & 4007.8 & 7024.5 & 8353.2 & 7417.1 \\
\hline
\end{tabular}

Krasnodar is characterized by the greatest volume of industrial production, which accounts for $83.6 \%$ of the total industrial production in the agglomeration [11]. The Severskiy and Dinskoy districts have the second position, with industrial production rates of about 4.5-6\%. The UstLabinskiy District demonstrates the lowest results in the entire agglomeration in terms of industrial production $(2.8 \%$ of the total volume) [11].

Moreover, the provided data proves that nowadays the industry is not yet being actively transferred from the nucleus of the agglomeration to its periphery, as it happens in developed post-industrial agglomerative structures. This process is only partially characteristic of the Krasnodar agglomeration. Industrial production is being transferred only to the Severskiy and Dinskoy districts, the territories closest to the nucleus. If we compare the dynamics of industrial production in the centre and in the periphery, it is obvious that currently businesses are not interested in leaving the agglomeration nucleus. For the rest of the agglomeration, this means missing opportunities related to the transfer of industrial enterprises to the periphery. However, as this process is evolutionary, the transfer is inevitable in future.

\section{CONCLUSION}

To conclude, being large regional economic centres, agglomerations are capable of attracting significant investment resources. It is likely to be connected with the development dynamics of such areas as industrial production, leisure and recreation, and social services. What is more, the concentration of population and industry in agglomerations as well as and their size are directly related to the volume of attracted investment. Thus, when developing and implementing the state policy for economic development, this factor should be taken into account. The policy should establish agglomerations as centres of regional development and frameworks for regional economies.

\section{REFERENCES}

[1] Krasnodar. Available at: https://ru.wikipedia.org/wiki/krdn.

[2] Agglomerations in Russia in the 20th century. Report. Available at: http://www.frrio.ru/uploads_files/Lappo.pdf.

[3] Investment portal of Krasnodar region. Available at: http://www.investkuban.ru/.

[4] Kutovoj S.I. Functions of city agglomerations in regional economy and their state support. Available at: https://cyberleninka.ru/article/n/funktsii-gorodskih-aglomeratsiy-vregionalnoy-ekonomike-i-ih-gosudarstvennaya-podderzhka.

[5] Lavrova T.G. Urban agglomeration of Krasnodar: development and management // The contours of global transformations: Politics, Economics, Law. 2015. No. 5. Pp. 80-89. 
[6] Lappo G. Agglomerations of Russia: innovative potential of the country инновационный потенциал страны // GRADO. 2011. No.1. Pp. 49-54.

[7] Lappo G., Polyan P., Selivanova T. Urban agglomerations of Russia. Available at: http://polit.ru/articule/2010/02/16/demoscope407/.

[8] 2.4 billion rubles will be allocated for the construction of schools and kindergartens in Kuban. Available at: http://kuban24.tv/item/navozvedenie-shkol-i-detskih-sadov-na-kubani-napravyat-2-4-mlrdrublej-168563.

[9] Neshchadin A., Prilepin A. Urban agglomerations as a tool of the dynamic socio-economic development of Russian regions. Available at: http://www. komfed. ru/section 136/section $141 \mathrm{Z674.}$

[10] Portal "Strategy for socio-economic development of Krasnodar Krai". Available at: http://kuban.av-web.ru/o-strategii/.

[11] The socio-economic situation of urban districts and municipal entities of Krasnodar Krai. Statistical Compendium. Krasnodar, 2019. 512 p.

[12] Demographia World Urban Areas (World Agglomerations). 8th Annual Edition: Version 2. July, 2012. Available at: http://www.demographia.com/db-worldua.pdf. 